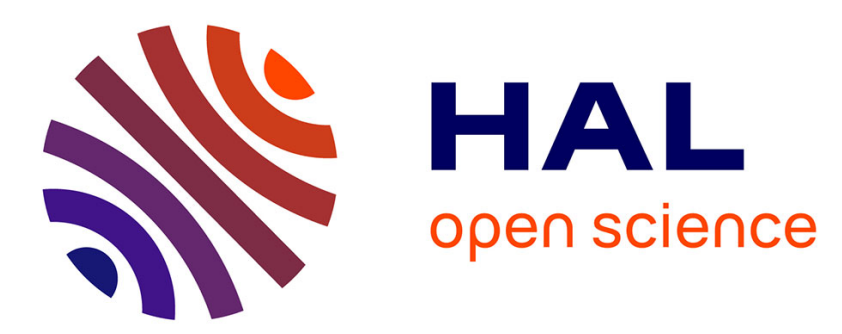

\title{
A statistical approach for predicting grassland degradation in disturbance-driven landscapes
}

Anne Jacquin, Goulard Michel, J. M. Shawn Hutchinson, Thomas Devienne, Stacy L. Hutchinson

\section{To cite this version:}

Anne Jacquin, Goulard Michel, J. M. Shawn Hutchinson, Thomas Devienne, Stacy L. Hutchinson. A statistical approach for predicting grassland degradation in disturbance-driven landscapes. Journal of Environmental Protection, 2016, vol. 7 (n 6), pp. 912-925. 10.4236/jep.2016.76081 . hal-01509642

\section{HAL Id: hal-01509642 \\ https://hal.science/hal-01509642}

Submitted on 18 Apr 2017

HAL is a multi-disciplinary open access archive for the deposit and dissemination of scientific research documents, whether they are published or not. The documents may come from teaching and research institutions in France or abroad, or from public or private research centers.
L'archive ouverte pluridisciplinaire HAL, est destinée au dépôt et à la diffusion de documents scientifiques de niveau recherche, publiés ou non, émanant des établissements d'enseignement et de recherche français ou étrangers, des laboratoires publics ou privés. 




\section{Open Archive TOULOUSE Archive Ouverte (OATAO)}

OATAO is an open access repository that collects the work of Toulouse researchers and makes it freely available over the web where possible.

This is an author-deposited version published in : http://oatao.univ-toulouse.fr/ Eprints ID : 17611

To link to this article : DOI :10.4236/jep.2016.76081

URL : http://dx.doi.org/10.4236/jep.2016.76081

To cite this version : Jacquin, Anne and Goulard, Michel and Hutchinson, J. M. Shawn and Devienne, Thomas and Hutchinson, Stacy L. A statistical approach for predicting grassland degradation in disturbance-driven landscapes. (2016) Journal of Environmental Protection, vol. 7 (n 6). pp. 912-925. ISSN 2152-2197

Any correspondance concerning this service should be sent to the repository administrator: staff-oatao@,listes-diff.inp-toulouse.fr 


\title{
A Statistical Approach for Predicting Grassland Degradation in Disturbance-Driven Landscapes
}

\author{
Anne Jacquin'1, Michel Goulard ${ }^{2}$, J. M. Shawn Hutchinson ${ }^{3 *}$, Thomas Devienne', Stacy L. \\ Hutchinson ${ }^{4}$ \\ ${ }^{1}$ Université de Toulouse, INPT, Ecole d'Ingénieurs de Purpan, UMR 1201 DYNAFOR, 75, voie du TOEC, Toulouse, \\ France \\ ${ }^{2}$ Institut National pour la Recherche Agronomique, UMR 1201 DYNAFOR, 24 Chemin de Borde Rouge-Auzeville, \\ Castanet Tolosan, France \\ ${ }^{3}$ Department of Geography, Kansas State University, Manhattan, KS, USA \\ ${ }^{4}$ Department of Biological and Agricultural Engineering, Kansas State University, Manhattan, KS, USA \\ Email: *shutch@ksu.edu
}

Received 1 April 2016; accepted 20 May 2016; published 23 May 2016

Copyright @ 2016 by authors and Scientific Research Publishing Inc.

This work is licensed under the Creative Commons Attribution International License (CC BY).

http://creativecommons.org/licenses/by/4.0/

(c) (i) Open Access

\begin{abstract}
Maintaining a land base that supports safe and realistic training operations is a significant challenge for military land managers which can be informed by frequent monitoring of land condition in relation to management practices. This study explores the relationship between fire and trends in tallgrass prairie vegetation at military and non-military sites in the Kansas Flint Hills. The response variable was the long-term linear trend (2001-2010) of surface greenness measured by MODIS NDVI using BFAST time series trend analysis. Explanatory variables included fire regime (frequency and seasonality) and spatial strata based on existing management unit boundaries. Several non-spatial generalized linear models (GLM) were computed to explain trends by fire regime and/or stratification. Spatialized versions of the GLMs were also constructed. For non-spatial models at the military site, fire regime explained little (4\%) of the observed surface greenness trend compared to strata alone $(7 \%-26 \%)$. The non-spatial and spatial models for the non-military site performed better for each explanatory variable and combination tested with fire regime. Existing stratifications contained much of the spatial structure in model residuals. Fire had only a marginal effect on surface greenness trends at the military site despite the use of burning as a grassland management tool. Interestingly, fire explained more of the trend at the non-military site and models including strata improved explanatory power. Analysis of spatial model predictors based on management unit stratification suggested ways to reduce the number of strata while achieving similar performance and may benefit managers of other public areas lacking sound data regarding land usage.
\end{abstract}

${ }^{*}$ Corresponding author.

How to cite this paper: Jacquin, A., Goulard, M., Hutchinson, J.M.S., Devienne, T. and Hutchinson, S.L. (2016) A Statistical Approach for Predicting Grassland Degradation in Disturbance-Driven Landscapes. Journal of Environmental Protection, 7, 912-925. http://dx.doi.org/10.4236/jep.2016.76081 


\section{Keywords}

\section{Fire Regime, Spatial Statistics, GLM Model, Grassland, Remote Sensing}

\section{Introduction}

The US Department of Defense is one of the largest land stewards in the nation [1]. Readily available and easily accessible military lands are required to support an array of training and testing activities by the armed forces of the United States. However, training activities ranging from vehicle-based maneuvers and indirect fire weapons to foot traffic are known to negatively affect environmental conditions [2]-[8].

Maintaining a land base that supports safe and realistic training operations is a significant challenge impacting the mission readiness of US military forces. A number of federal laws (e.g., Sikes Act of 1960, National Environmental Policy Act of 1969) and military regulations outline specific requirements for natural resource conservation and management plans and activities, including that sustainable use should be a programmatic goal within the US Army [9]-[11]. Given the geographic extent of training sites and their diverse settings, including deserts, tropical and temperate forests, semi-arid grasslands, and arctic landscapes, defining and agreeing on metrics to measure "sustainable use" is difficult. This difficulty is compounded when superimposing spatially and temporally unique military training disturbances on very different ecosystems.

As in temperate grasslands and savannas across the world, fire frequency and timing can have significant impacts on the spatial pattern of plant productivity, vegetation structure, and nutrient cycling in the Flint Hills ecoregion of North America [12]-[15]. For example, frequent burning typically results in prairie dominated by $\mathrm{C} 4$ grasses, with lower species richness and diversity, and higher average peak-season aboveground biomass. When considered with other factors such as weather and climate, topographic position, grazing and other anthropogenic disturbances, the impact of fire on grassland dynamics is even more complex [16]-[20].

In this study, promoting sustainable grasslands is considered the primary objective with sustainability being defined using results from a long-term analysis of vegetation trends derived from remotely-sensed estimates of normalized difference vegetation index (NDVI) data. The influence of fire and land use practices on grassland vegetation trends is assessed to provide land managers with site-specific feedback about progress towards their training land sustainability goals.

Spatial statistical tools are used to analyze spatiotemporal trends in vegetation and fire regime using a time series of multisource remote sensing images over the period 2001-2010. This approach has previously been used by [21] who studied the role of fire on savanna vegetation in Madagascar. As in this previous work, results from non-spatial and spatial statistical analyses with spatial stratification are compared to identify the method that best explains vegetation dynamics. The spatial generalized linear model (GLM) is a classical tool in the spatial statistics toolbox. Here, a hierarchical coupled logistic multinomial model with a spatial auto normal random component was used. However, because the spatial stratifications used in this study were not always constructed from areas with homogeneous environmental conditions, land use practices, or human impacts, a new approach was proposed and implemented to construct improved and simplified spatial stratifications that were better adapted to the response variable. This approach may benefit other research efforts in disturbed environments where the landscape exhibits similar heterogeneity. Though implemented in a basic form here, future stratifications could be defined using hierarchical spatial models that operate in a manner similar to non-supervised image classification.

This research was conducted at Fort Riley, a US Army installation located in northeastern Kansas, within the framework of the Army's Integrated Training Area Management (ITAM) program. In conjunction with installation ITAM staff, we seek to demonstrate methods for continuously monitoring, assessing and identifying trends in key indicators of military training land sustainability over appropriate timescales, rapidly analyze data, and ensure information is available when needed by military land managers. Though military lands are the focus here, these objectives are equally applicable for effective management of other grasslands and savannas in the western US, South America, Europe, Africa, and Asia. 


\section{Materials and Methods}

\subsection{Study Area}

Fort Riley is a 41,128 ha U.S. Army installation in northeast Kansas $\left(39^{\circ} 11^{\prime} \mathrm{N}, 96^{\circ} 48^{\prime} \mathrm{W}\right)$, on the Kansas River, between Junction City and Manhattan within Geary, Riley and Clay counties. The installation is located within both the Flint Hill ecoregion [22] and the Central Great Plains Winter Wheat and Range land resource region [23]. Soils are productive and typically consist of clay uplands combined with loamy uplands, limy soils, and loamy lowlands. Vegetation at Fort Riley is dominated by grasslands (81\%) followed by woodlands (16\%) and shrublands (3\%). Dominant plant species in grassland areas include big bluestem (Andropogon gerardii), Indiangrass (Sorghastrum nutans), switchgrass (Panicum virgatum), and little bluestem (Schizachyrium scoparium). These characteristic tallgrass prairie species are actively managed using prescribed fire during the fall, winter, and spring seasons. However, wildfires resulting from military training may occur during any season.

The installation is subdivided into 103 administrative units within which military training occurs. Disturbances from military training on Fort Riley include a variety of on- and off-road field maneuvers (including tracked and wheeled combat vehicle operations), mortar and artillery fire, small arms fire, and aircraft flights. For the past four decades, the majority of combat vehicle maneuvers take place in the western part of the installation.

The Konza Prairie Biological Station (KPBS) was included in this analysis to contrast vegetation change measured at Fort Riley with that at a relatively natural grassland site. KPBS (3487 ha) is owned by the Nature Conservancy and operated by the Division of Biology at Kansas State University (http://kpbs.konza.ksu.edu). One of the U.S. National Science Foundation's Long Term Ecological Research Sites, KPBS has similar vegetation, soils and climate due to its close proximity (less than $10 \mathrm{~km}$ ) to Fort Riley.

It is assumed that any differences observed between the two sites are caused by varying anthropogenic activities and land management practices. Though not impacted by military training, vegetation at KPBS is influenced by other human actions including prescribed burning. The KPBS site is subdivided into 48 sub-watershed areas which serve as experimental units where specific combinations of fire (by both season and frequency) and grazing (including both domestic cattle and native bison) are applied. Figure 1 shows the general vegetation types and spatial stratification used by land managers for the two study areas.

\subsection{Data}

Data used in this analysis consists of vegetation activity change and fire regime data. All procedures used to process data for Fort Riley were also applied for KPBS. The study period is limited to 2001-2010 to match the study duration of the prerequisite vegetation trend analysis work previously completed for Fort Riley and KPBS and the lack of data needed to characterize the fire regime (high spatial resolution images) after 2010.

\subsubsection{Vegetation Activity Change Data}

A vegetation change indicator was developed to characterize long-term trends in activity over the study period (Figure 2). The indicator was obtained using a temporal decomposition method applied to a time series of MODIS 16-day maximum value composite NDVI images (MOD13Q1) with a spatial resolution of $250 \mathrm{~m}$ between January 2001 and December 2010. The method, described in [25] consists of three steps: 1) NDVI time series decomposition using BFAST based on LOESS [26]; 2) analysis of the BFAST trend component using linear regression; and 3) identification of significant positive or negative trend slopes using a Student's t-test. This method has already been applied to the Fort Riley and KPBS study areas [27].

\subsubsection{Fire Regime Data}

A fire regime indicator was also developed to characterize burning activities according to season and frequency by analyzing a time series of multisource remote sensing data for the period 2001-2010. The primary remote sensing data were high spatial resolution (HSR) images most appropriate for delineating burn scars at local and regional scales [28]. A total of 83 Landsat 5 TM images with a spatial resolution of $30 \mathrm{~m}$ were acquired and burn scars extracted using a combination of unsupervised classification of the near-infrared band with CAPI techniques [29].

Due to persistent cloud contamination during the study period, it was impossible to acquire and classify HSR images at a frequency sufficient to adequately identify burn scars. This was especially a problem in 2004-2005, 


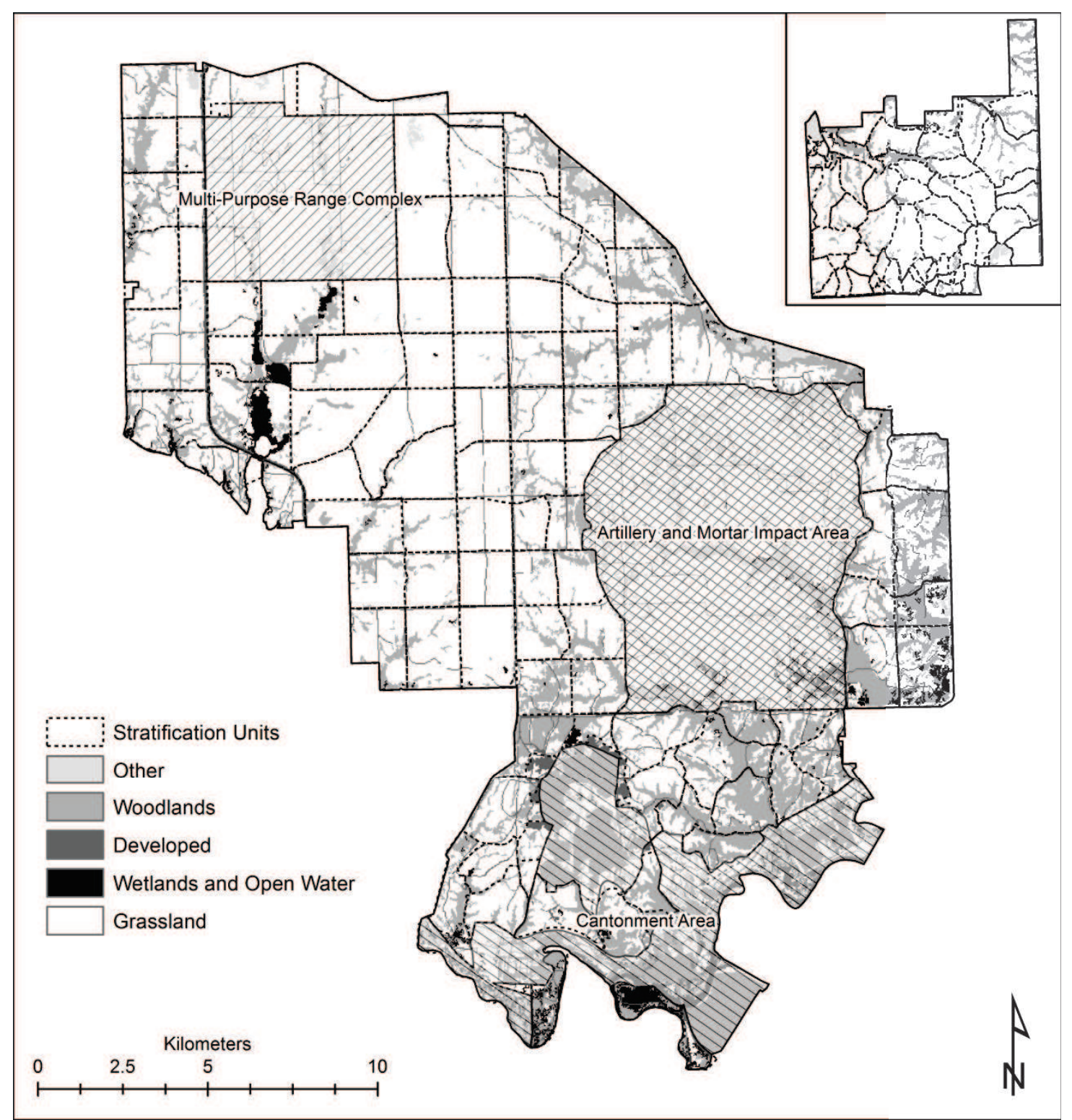

Figure 1. Generalized map of landuse and landcover types at Fort Riley, Kansas and Konza Prairie Biological Station overlaid with local administrative and management boundaries (black lines) that serve as a spatial stratification. Landuse/landcover data from the 2011 National Landcover Database [24].

2007-2008, and 2009-2010 when the November through March period was not well covered by Landsat 5. To fill these gaps, 135 additional MODIS Burned Area Product (MCD45) images were used to complement the HSR time series. Produced by the MODIS Fire Team at the University of Maryland

(http://modis-fire.umd.edu/pages/BurnedArea.php), the Burned Area Product provided monthly images of burned pixels at a $500 \mathrm{~m}$ spatial resolution. Though the spatial resolution is coarse, preventing detection of small and fragmented burns, the MCD45 images were a practical and inexpensive source of data to ensure a continuous and reliable source of fire information within the time series.

Next, monthly burned area maps were created for each year and used to calculate annual burned area maps. To ensure compatibility with the vegetation change indicator, monthly burned area maps were overlaid with a grid of the same spatial resolution. Only grid cells with a minimum burned area of $80 \%$ were retained for further analysis. Summing the annual maps over the study period yielded fire frequency (Figure 3(a)). Annual burned area maps were also created to identify when fires occurred (e.g., seasonality) (Figure 3(b)). Three seasons were 


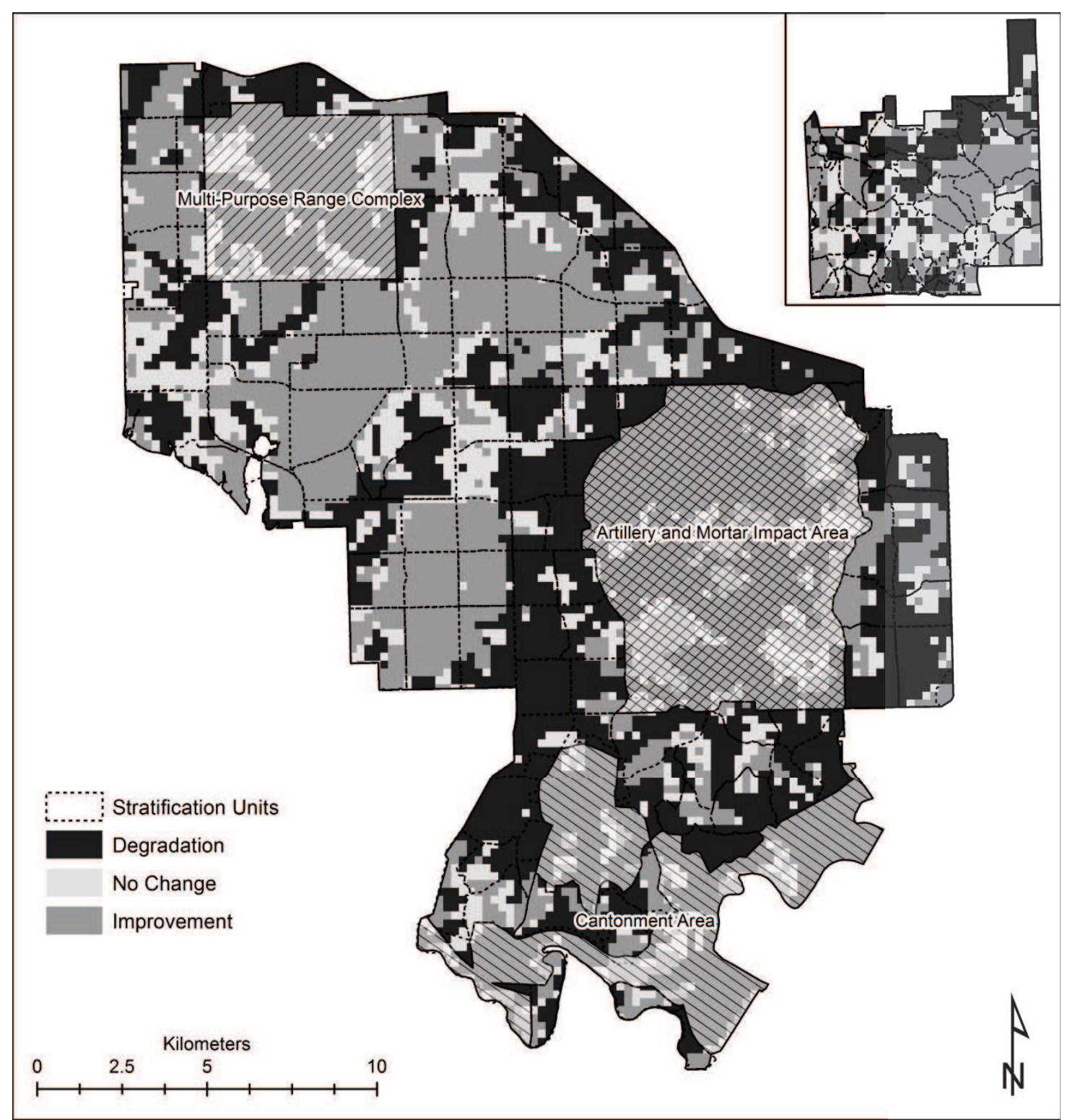

Figure 2. Vegetation change activity indicator map for the period 2001-2010 for Fort Riley, Kansas and Konza Prairie Biological Station. Areas in dark gray indicate a decrease in vegetation condition (degradation). Areas in light gray and white indicate an increase in vegetation activity (improvement) and no change, respectively. The indicator was obtained using a temporal decomposition method applied to a time series of MODIS 16-day maximum value composite NDVI images as reported in [27].

defined: Fall (September-October-November), winter (December-January-February), and spring (March-AprilMay). In determining both fire frequency and seasonality (i.e., fire regime), it was assumed that an individual pixel could burn only once per year with the timing of that burn defining the season. With information on both fire frequency and seasonality, a fire regime indicator consisting of 13 classes was defined.

\subsection{Analysis Methods}

\subsubsection{Statistical Model Development}

Modeling the relationship between explanatory and response variables is a fundamental activity encountered in statistics. Multiple linear regression is used to investigate the relationship between a single response variable and several explanatory variables. Often, the response is simply a designation of one or two possible outcomes (i.e., 


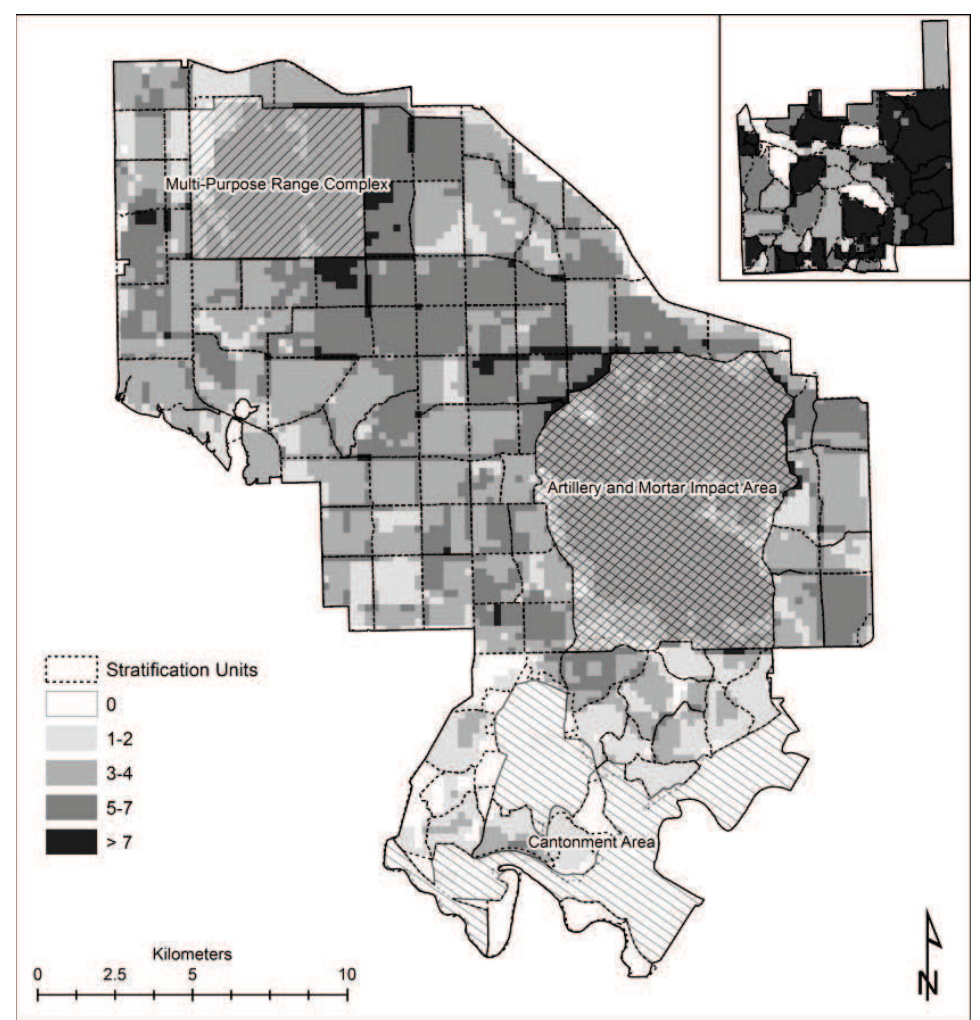

(a)

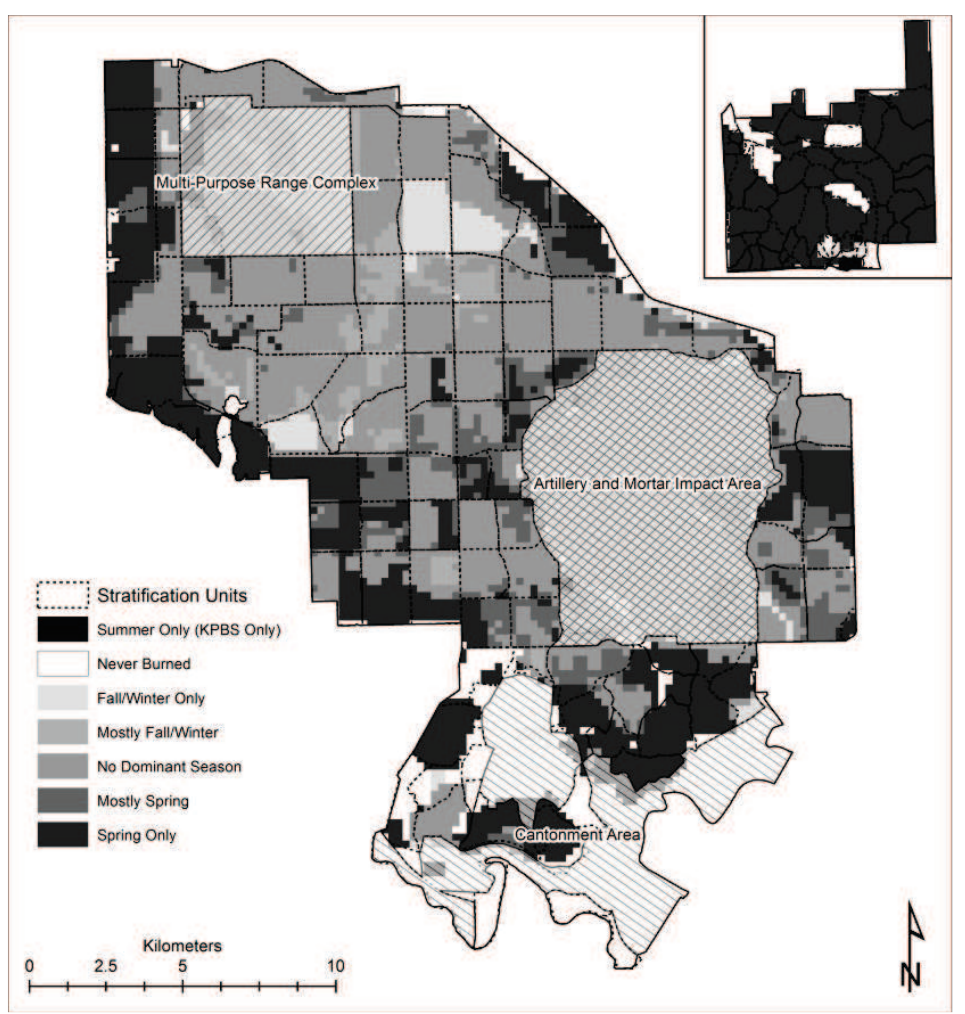

(b)

Figure 3. Fire frequency (a) and seasonality (b) for Fort Riley, Kansas and Konza Prairie Biological Station for the period 2001-2010. Combined frequency and seasonality yielded 13 total fire regime classes used in the analysis. 
a binary response). In this study, the possible outcomes are "degraded" or "non-degraded" vegetation activity and this binary response is examined in relation to fire regime and/or other anthropogenic activities represented by stratification using non-spatial and spatial generalized linear models (GLM).

The grassland vegetation activity change map was first overlaid with the fire regime data. Next, GLM models were computed on a per-pixel basis to study how well fire regime and/or stratification explained degraded vegetation activity. In the first non-spatial model, where independence between observations was assumed, a classical estimation method was used. Due to the nature of the response variable, the model was a binomial GLM with a probability of success depending on the characteristics of each observation site. The link between this probability and the linear predictor based on individual characteristics is the logit and the estimation was done by maximum likelihood [30].

Because correlation between observations was suspected, a second model accounting for spatial correlation was applied. In this model, an existing spatially random field was assumed which takes into account what is not explained in the independent model. Given this unobserved random field, the model adds to the linear predictor the value of the random field at the observation site. The maximum likelihood method, however, is now problematic because the likelihood cannot be derived analytically and must be approximated. Instead, the Bayesian Markov Chain Monte Carlo method based on Metropolis dynamics was used to estimate model parameters. The estimates are then taken as the posterior mean [31].

Both types of models (non-spatial and spatial) were evaluated with two metrics. The first was the Akaike Information Criterion (AIC) which summarizes the tradeoff between model accuracy and complexity [32] [33]. Low AIC values for a model indicate superior explanatory power. The second metric was a ratio equal to $1 \mathrm{mi}-$ nus the residual deviance divided by null deviance (1 - (residual deviance / null deviance)). If the ratio is low then, at the level of the study area, other explanatory variables not included in the model should be considered.

\subsubsection{Definition of Tested Models and Analysis Procedures}

Five models using different explanatory variables were tested and their ability to explain degraded vegetation activity assessed. The initial assumption was that vegetation degradation would be explained adequately by only the fire regime variable (model 1), or only stratification (model 2), or a combination of fire regime and stratification (model 3). However, the original stratification, especially that at Fort Riley, was not specifically designed for use in monitoring grassland vegetation dynamics. To address this, a simplified stratification more adapted to the response variable was also tested. This simplified stratification was developed by analyzing the distribution of the model predictor based only on the original stratification (model 2) as a function of the stratification units. Two additional models were then developed. One only with simplified stratification (model 4) and one with fire regime and simplified stratification (model 5).

Comparing model 1 vs. model 2 and model 2 vs. model 3 provided results sufficient to assess the effect of fire regime on grassland vegetation degradation. The comparison of model 2 to model 4 or model 5 allowed evaluation of the simplified stratification and its ability to better explain observed vegetation degradation as well as its potential for serving as a spatial framework for monitoring grassland condition in the future.

\subsubsection{GLM Validation Procedure}

Each GLM model generates a probability map for vegetation degradation. Model performance is then validated using two different reference datasets. The first is the vegetation degradation class resulting from the previously mentioned MODIS NDVI trend analysis. The second is a new HSR vegetation degradation class from a change analysis performed using two Landsat 5 TM images acquired near the beginning (08/05/2001) and end (08/30/ 2010) of the study period. This method was recommended by [34], has been proven well adapted for grassland ecosystems [35] [36], and has been previously used to validate vegetation change activity for the Fort Riley and KPBS study areas [27].

The HSR dataset consists of a raster with the same spatial resolution as the vegetation activity change map $(250 \mathrm{~m})$ in which each grid cell corresponds to one of two classes (degraded or non-degraded) based on the interpretation of NDVI change derived from the Landsat 5 TM images. Since the GLM model estimates only a probability of vegetation degradation, only the NDVI change class for degraded vegetation is retained during this validation step.

A contingency matrix was constructed with rows representing the reference data (Landsat 5 NDVI change class for degraded vegetation or MODIS NDVI trend class for degraded vegetation) and columns with two 
classes of vegetation degradation probabilities $(>0.50$ and $\leq 0.50)$.

\section{Results}

The ratio $(1-$ residual deviance/null deviance $) * 100$ was used to determine how well explanatory variables in the five GLM models explained variability in the vegetation activity change indicator. Associated AIC values were also calculated to characterize the relative explanatory power of each model (Table 1).

\subsection{Impact of Fire on Vegetation Degradation}

To assess the effect of fire regime on vegetation activity change, results from GLM models with only the fire regime variable (model 1) were compared with those of GLM models using only stratification (model 2). Fire alone explains very little at Fort Riley $(4 \%-11 \%)$ versus to stratification alone (26\% - 31\%). The marginal effect of fire on vegetation dynamics is confirmed when also considering the results of the GLM model with fire and stratification (model 3). The combination of fire regime and stratification does not improve the explanatory power of the model $(27 \%-31 \%)$. This same applies to KPBS, except that the effect of fire on vegetation activity change is higher than Fort Riley (14\% - 29\%).

At Fort Riley, regardless of the GLM model, using a spatial approach in the statistical analysis is needed. Spatial versions of the GLM models provide a 4\% - 7\% improvement in performance compared to non-spatial models with the added benefit of systematically lower AIC values. The situation at KPBS is slightly different. Model spatialization is not needed if the analysis is done with the original stratification, as the percentage of vegetation activity change explained and AIC values are nearly the same with both non-spatial and spatial models. At KPBS, the original stratification already accounts for the type and distribution of explanatory variables in the models. However, when modifying the original stratification (model 4), spatialization provides a $9 \%$ improvement in model performance with a decrease in AIC values from 577 to 511.

\subsection{Assessment of Simplified Stratification Model Performance}

By analyzing the range of predictor values for GLM models with only stratification (model 2) for each of the original management units (103 training areas at Fort Riley and 48 sub-watersheds at KPBS), a simplified stratification was proposed. For both study areas, this simplification consists only of five strata obtained after reclassification of training areas or sub-watersheds.

Results from the GLM model with only original stratification (model 2) were compared to those of the GLM model with only simplified stratification (model 4). At Fort Riley and KPBS, simplification explains nearly the same amount of vegetation activity change but with only five strata. As already seen with the original stratification, adding the fire regime variable to simplified stratification in a GLM model (model 5) does not improve the ability to explain vegetation activity change. Therefore, the GLM model with only simplified stratification was considered most appropriate.

Table 1. Percentage of vegetation degradation explained by spatial and non-spatial GLM models. The value for $\mathrm{n}$ is the total number of modalities for explanatory variables used in each GLM model.

\begin{tabular}{|c|c|c|c|c|c|c|}
\hline \multirow{3}{*}{ GLM Models } & \multicolumn{6}{|c|}{$\%$ of Vegetation Degradation Explained } \\
\hline & \multicolumn{3}{|c|}{ Fort Riley Models } & \multicolumn{3}{|c|}{ KPBS Models } \\
\hline & $\mathrm{n}$ & Non-Spatial (AIC) & Spatial (AIC) & $\mathrm{n}$ & Non-Spatial (AIC) & Spatial (AIC) \\
\hline $\begin{array}{l}\text { Model with only fire } \\
\qquad(\text { model } 1)\end{array}$ & 13 & $\begin{array}{c}4 \% \\
(8244)\end{array}$ & $\begin{array}{c}11 \% \\
(7614)\end{array}$ & 13 & $\begin{array}{l}14 \% \\
(806)\end{array}$ & $\begin{array}{l}29 \% \\
(673)\end{array}$ \\
\hline $\begin{array}{l}\text { Model with only original stratification } \\
\text { (model } 2)\end{array}$ & 103 & $\begin{array}{c}26 \% \\
(6537)\end{array}$ & $\begin{array}{c}31 \% \\
(6118)\end{array}$ & 48 & $\begin{array}{l}39 \% \\
(650)\end{array}$ & $\begin{array}{l}40 \% \\
(653)\end{array}$ \\
\hline $\begin{array}{l}\text { Model with fire and original stratification } \\
\qquad(\text { model 3) }\end{array}$ & 116 & $\begin{array}{c}27 \% \\
(6507)\end{array}$ & $\begin{array}{l}31 \% \\
(6092)\end{array}$ & 61 & $\begin{array}{l}40 \% \\
(661)\end{array}$ & $\begin{array}{l}43 \% \\
(646)\end{array}$ \\
\hline $\begin{array}{l}\text { Model with only simplified stratification } \\
\text { (model 4) }\end{array}$ & 5 & $\begin{array}{l}23 \% \\
(6575)\end{array}$ & $\begin{array}{l}27 \% \\
(6234)\end{array}$ & 5 & $\begin{array}{l}37 \% \\
(577)\end{array}$ & $\begin{array}{l}46 \% \\
(511)\end{array}$ \\
\hline $\begin{array}{l}\text { Model with fire and simplified stratification } \\
\qquad(\text { model 5) }\end{array}$ & 18 & $\begin{array}{l}23 \% \\
(6579)\end{array}$ & $\begin{array}{l}27 \% \\
(6296)\end{array}$ & 18 & $\begin{array}{l}37 \% \\
(587)\end{array}$ & $\begin{array}{l}40 \% \\
(580)\end{array}$ \\
\hline
\end{tabular}




\subsection{Validation of GLM Model with Simplified Stratification}

The vegetation degradation probability maps for Fort Riley and KPBS generated by the GLM model with only simplified stratification are shown in Figure 4. Black and dark gray areas correspond to the highest probabilities of vegetation degradation as explained by the five new strata, while sites in light gray or white suggest a low probability of vegetation degradation.

Evaluation of the contingency matrix helps validate the vegetation degradation probability maps from the selected GLM model (Table 2). Agreement is high at Fort Riley (59\% - 76\%) and moderate to relatively high at KPBS $(40 \%-62 \%)$ based on the reference data used. These validation results suggest the new simplified stratification is capable of highlighting areas of degradation, especially at Fort Riley. Identifying concentrations, or hot spots, of vegetation degradation can focus the attention of military land managers on specific areas where anthropogenic activities are having a negative impact on vegetation activity.

\section{Discussion}

Results from this analysis provide two major advances. First, from a thematic point of view and contrary to what

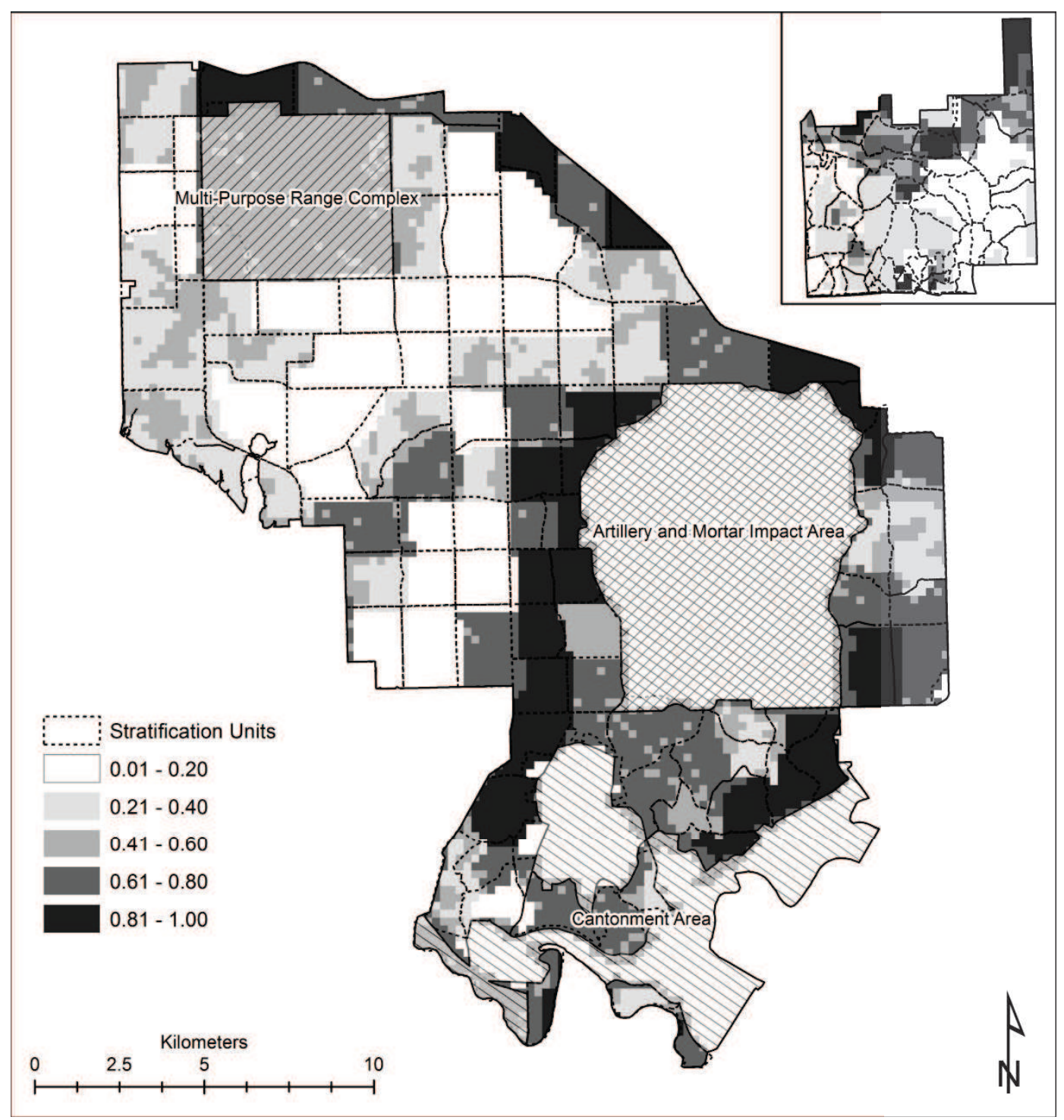

Figure 4. Probability of vegetation degradation for Fort Riley, Kansas (left) and Konza Prairie Biological Station (right). Probabilities are based on the GLM model results using only the five simplified strata as the explanatory variable. 
Table 2. Contingency matrix with validation results for the Fort Riley and KPBS vegetation degradation probability maps. Landsat and MODIS NDVI change classes are considered the reference. Numbers are percentage of vegetation degradation probability pixels belonging to the Landsat or MODIS NDVI change class.

\begin{tabular}{lccc}
\hline \multicolumn{2}{c}{ Reference Data } & \multicolumn{2}{c}{ Vegetation Degradation Probability Classes from GLM Model 4} \\
\cline { 3 - 4 } \multicolumn{2}{c}{ for Vegetation Degradation Class } & $>0.50$ & $\leq 0.50$ \\
\hline \multirow{2}{*}{ Fort Riley } & Landsat NDVI change class & 59 & 41 \\
& MODIS NDVI change class & 76 & 24 \\
\multirow{2}{*}{ KPBS } & Landsat NDVI change class & 40 & 60 \\
& MODIS NDVI change class & 62 & 38 \\
\hline
\end{tabular}
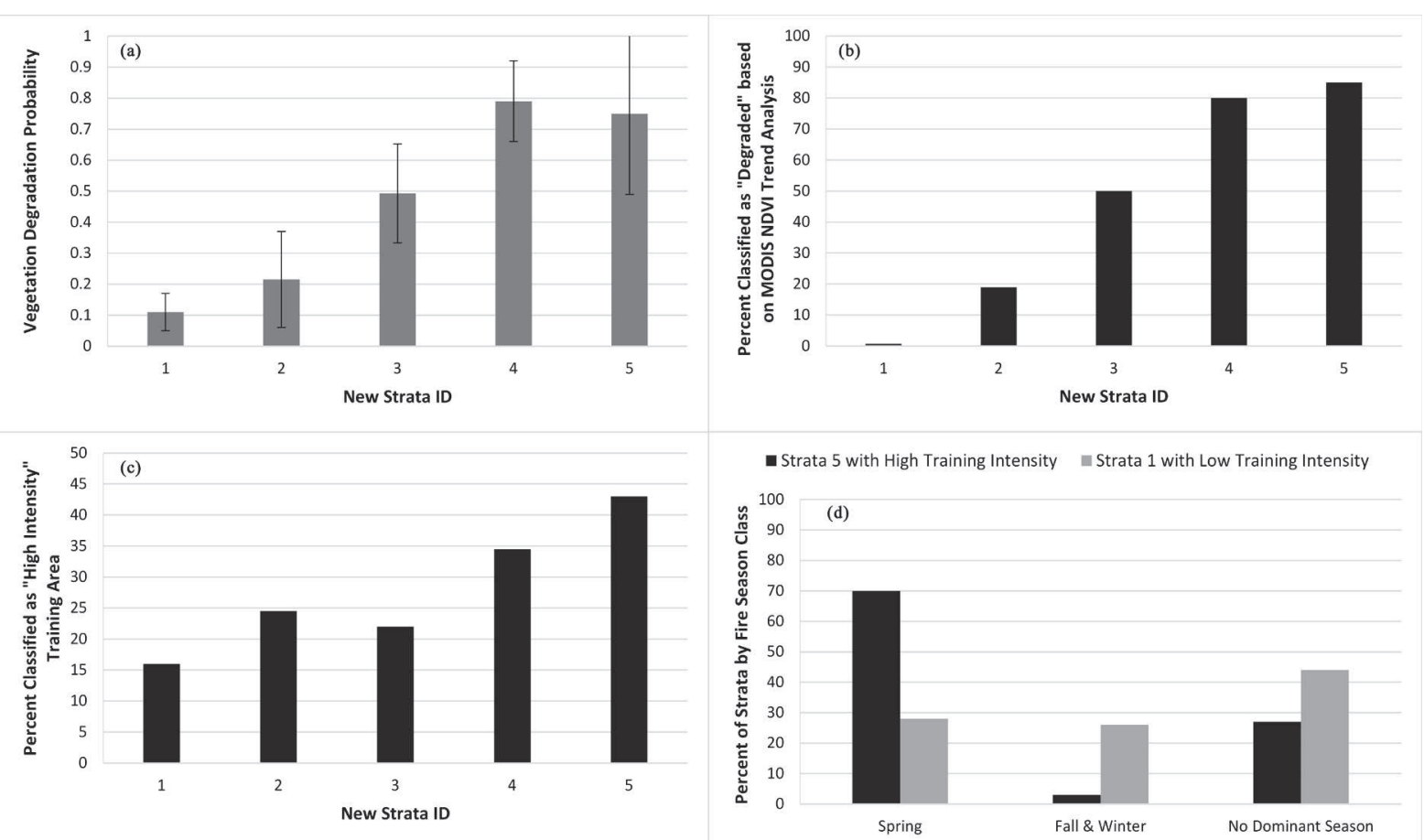

Figure 5. Characterization of the new simplified strata at Fort Riley by average vegetation degradation probability (a); by percentage of area classified as "DEGRADED VEGETATION" based on MODIS NDVI trend analysis (b); by percentage of areas classified as having a "HIGH INTENSITY" of military training activities (c); and by the percentage of strata area as a function of fire season (d).

was expected, fire regime did not adequately explain patterns of vegetation activity change. At both sites, based on comparison of models with only original stratification (model 2) with original stratification and fire (model 3 ), vegetation degradation is better explained by the original stratification. This is especially true at Fort Riley and points to disturbances other than fire as the driver of local grassland trends.

Second, from a methodological point of view, the soundest approach for identifying a model that best explained vegetation activity change involved first using a model with original stratification to form a new stratification more adapted to the response variable using a spatial approach. At Fort Riley, where simplified stratification is very informative (almost 3 times more than fire regime only), the five new strata were used to characterize the probability of vegetation degradation provided by the GLM model (Figure 5(a)). Strata 4 and 5, respectively, have an average vegetation degradation probability of 0.79 and 0.75 . This is significantly higher than that obtained for strata 1,2 , and 3 .

The role of military training activities was also investigated. High intensity training associated with mechanized military maneuvers has been cited as the cause of increased bare soil, reduced plant cover, soil compaction, and compositional shifts in plant communities [9] [37]-[40]. A map of military training intensity was created using a combination of expert knowledge and information from related literature (Denker, pers. comm.; Hut- 
chinson pers. comm.; [41]). Training areas were then classified using two levels (high and low) of training intensity (Figure 6).

In strata 4 and 5 , the percentage area classified as having high military training intensity is almost double that of strata 1, 2, and 3 (Figure 5(c)). Strata 4 and 5 also represent areas where vegetation degradation identified by MODIS NDVI trend analysis was most concentrated, with $80 \%$ of strata 4 and $85 \%$ of strata 5 being classified as degraded (Figure 5(b)). These same strata have the highest probabilities of vegetation degradation as predicted by the GLM model.

Though fire appears to have only a minimal impact on vegetation dynamics based on GLM model results, fire regime was also analyzed within the new simplified strata. All strata were almost entirely burned (87\%) during the 2001-2010 study period at predominantly low or very low frequency (i.e., no more than one fire every three years). In strata 5, the zone with the highest level of vegetation degradation (85\%) and high intensity training (43\%), fire typically occurred in spring (70\%). In strata 1 , where vegetation degradation and training intensity were both low $(0.4 \%$ and $16 \%$, respectively), fire occurred almost equally across the spring, fall, and winter seasons (Figure 5(d)).

Spring burning in the Flint Hills ecoregion removes senescent vegetation from the previous growing season to

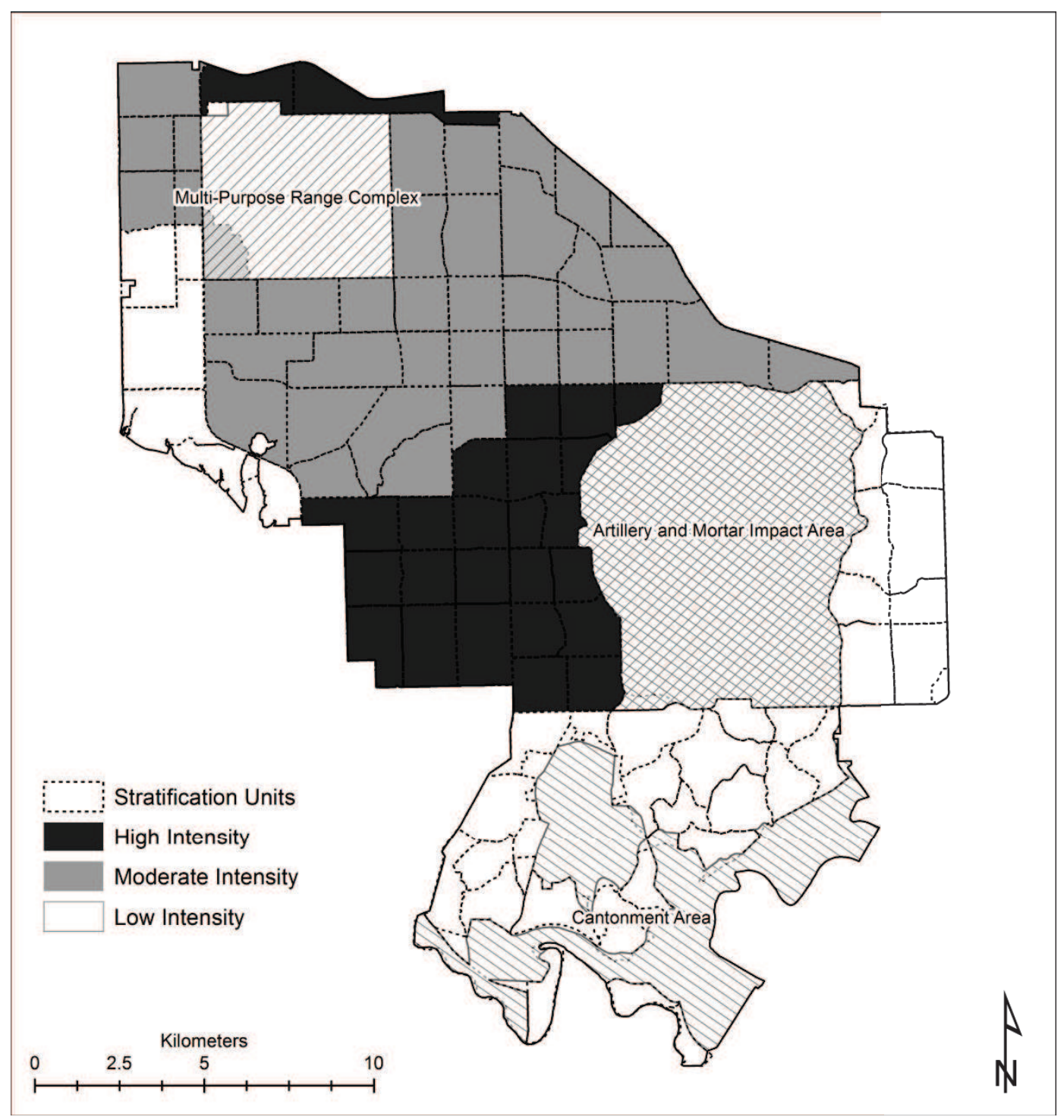

Figure 6. Estimated military training intensity at fort riley, kansas. numbers are identification labels for actual training areas in use at fort riley. 
promote growth of new grasses. Annual spring fires favor $\mathrm{C} 4$ vegetation over $\mathrm{C} 3$ species, but also cause longterm increases in bare ground [42] [43]. Native C4 grasses in Kansas are more resilient to, and recover more quickly from, damage caused by military vehicles during off-road maneuvers, while areas dominated by $\mathrm{C} 3$ species tend to be more sensitive training [44]. It is important to note that over a third of the annual precipitation at Fort Riley also occurs during the spring months. That spring fires are a common feature of the strata also experiencing the greatest percentage of vegetation degradation and highest training intensities suggest that the temporal correspondence of fire, rainfall, and military training are contributing to increased vegetation damage and, perhaps, soil erosion.

Considering KPBS, strata 5 had an average vegetation degradation probability of $0.69 \%$ and $61 \%$ of the area is classified as degraded based on MODIS NDVI trend analysis. Strata 1 has a very low probability of degradation $(0.03)$ and $99 \%$ of the area is classified as non-degraded. Both strata $5(75 \%)$ and $1(90 \%)$ were almost entirely burned during the study period with spring the most common season of burning ( $96 \%$ for strata 5 and $100 \%$ for strata 1 ). The main difference between the strata is fire frequency and other land uses. In strata 1,56\% of the area is affected by annual burns without any grazing pressure and $36 \%$ by one fire every four years with bison grazing conducted annually between May and October. In strata 5, fire frequency is variable but well balanced ( $54 \%$ low and $46 \%$ high frequency), but $40 \%$ of the area is under intensive grazing by cattle (northeast) and $37 \%$ is used for trail-based recreation (north central). Spring fires at KPBS seem to be a stabilizing factor for the grassland ecosystem with vegetation degradation due mainly to grazing activities combined with fire frequency and human disturbances.

\section{Implications}

There appears to be contrasting approaches to fire management at Fort Riley. In areas where training intensities are high, spring fires are perhaps used to promote grassland health where military training disturbances are significant and frequent. In other training areas, no fire regime dominates. While the literature and results here from KPBS support spring burning as a good practice from a grassland resource perspective, when combined with frequent and intense training during the wettest time of the year, it may actually be counterproductive and amplify vegetation degradation. At minimum, the influence of military training on vegetation dynamics is important and serves to minimize any potential benefit realized from a typical Flint Hills fire regime.

To confirm such conclusions, more detailed and temporally consistent training data are required. While these data do exist, they are embedded within complex US Army database management systems and are difficult to extract for use in natural resource studies. Until such a time when training data are routinely available for land managers, the new simplified strata presented here may be used as a spatial guide to modify training schedules and prevent further declines in vegetation condition where degradation has been predicted and measured. Land managers suffering from similar data deficiencies in land usage, such as off-road vehicle use in public recreation areas, may also find utility in defining custom strata for their sites.

\section{Acknowledgements}

This work was supported by the French Agence Nationale de la Recherche through the Moduland project (ANR-11-BSH1-005). Funding to support international research collaboration was provided by Ecole d'Ingénieurs de Purpan and the Geographic Information Systems Spatial Analysis Laboratory (GISSAL) at Kansas State University. Additional travel funding was provided by the National Polytechnic Institute (INP) of Toulouse to support researcher exchange.

\section{References}

[1] Congressional Research Service (2012) Federal Land Ownership: Overview and Data. https://www.fas.org/sgp/crs/misc/R42346.pdf

[2] Chancellor, W.J. (1977) Compaction of Soil by Agricultural Equipment. University of California-Berkeley, Division of Agriculture Science Bulletin, University of California, Berkeley.

[3] Houston, S.T., Doe, W.W. and Shaw, R.B. (2001) Environmental Risk of Army Ranges and Impact Areas: An Ecological Framework for Assessment. Federal Facilities Environmental Journal, 11, 93-111. http://dx.doi.org/10.1002/ffej.3330120110 
[4] Liu, K., Ayers, P., Howard, H. and Anderson, A. (2009) Influence of Turning Radius on Wheeled Military Vehicle Induced Rut Formation. Journal of Terramechanics, 46, 49-55. http://dx.doi.org/10.1016/j.jterra.2009.02.004

[5] Milchunas, D.G., Schultz, K.A. and Shaw, R.B. (1999) Plant Community Response to Disturbance by Mechanized Military Maneuvers. Journal of Environmental Quality, 28, 1533-1547. http://dx.doi.org/10.2134/jeq1999.00472425002800050019x

[6] Thurow, T.L. (1991) Hydrology and Erosion. In: Heitschmidt, R.K. and Stuth, J.W., Eds, Grazing Management: An Ecological Perspective, Timber Press, Portland, 141-160.

[7] Thurow, T.L., Warren, S.D. and Carlson, D.H. (1993) Tracked Vehicle Traffic Effects on the Hydrologic Characteristics of Central Texas Rangeland. Transactions of the American Society of Agricultural Engineers, 36, 1645-1650. http://dx.doi.org/10.13031/2013.28507

[8] Quist, M.C., Fay, P.A., Guy, C.S., Knapp, A.K. and Rubenstein, B.N. (2003) Military Training Effects on Terrestrial and Aquatic Communities on a Grassland Military Installation. Ecological Applications, 13, 432-442. http://dx.doi.org/10.1890/1051-0761(2003)013[0432:MTEOTA]2.0.CO;2

[9] Department of Defense, Under Secretary for Acquisition, Technology, and Logistics (2011) Department of Defense Instruction 4715.03, March 18 2011. http://www.dtic.mil/whs/directives/corres/pdf/471503p.pdf

[10] Department of the Army (1988) Environmental Effects of Army Actions (Army Regulation 200-2). Headquarters, Department of the Army, Washington DC.

[11] Department of the Army (2005) The Army Sustainable Range Program (Army Regulation 350-19). Headquarters, Department of the Army, Washington DC.

[12] Towne, E.G. and Owensby, C. (1984) Long-Term Effects of Annual Burning at Different Dates in Ungrazed Kansas Tallgrass Prairie. Journal of Range Management, 37, 392-397. http://dx.doi.org/10.2307/3899622

[13] Collins, S.L., Glenn, S.M. and Gibson, D.J. (1995) Experimental Analysis of Intermediate Disturbance and Initial Floristic Composition: Decoupling Cause and Effect. Ecology, 76, 486-492. http://dx.doi.org/10.2307/1941207

[14] Abrams, M.D. and Hulbert, L.C. (1987) Effect of Topographic Position and Fire on Species Composition in Tallgrass Prairie in Northeast Kansas. American Midland Naturalist, 117, 442-445. http://dx.doi.org/10.2307/2425988

[15] Ojima, D.S., Schimel, D.S., Parton, W.J. and Owensby, C.E. (1994) Long- and Short-Term Effects of Fire on Nitrogen Cycling in Tallgrass Prairie. Biogeochemistry, 24, 67-84. http://dx.doi.org/10.1007/BF02390180

[16] Abrams, M.D., Knapp, A.K. and Hulbert, L.C. (1986) A Ten-Year Record of Aboveground Biomass in a Kansas Tallgrass Prairie: Effects of Fire and Topographic Position. American Journal of Botany, 73, 1509-1515. http://dx.doi.org/10.2307/2443856

[17] Collins, S.L. (1987) Interaction of Disturbances in Tallgrass Prairie: A Field Experiment. Ecology, 68, 1243-1250.

[18] Towne, E.G. and Knapp, A.K. (1996) Biomass and Density Responses in Tallgrass Prairie Legumes to Annual Fire and Topographic Position. American Journal of Botany, 83, 175-179. http://dx.doi.org/10.2307/2445935

[19] Briggs, J.M. and Knapp, A.K. (1995) Interannual Variability in Primary Production in Tallgrass Prairie: Climate, Soil Moisture, Topographic Position, and Fire as Determinants of Aboveground Biomass. American Journal of Botany, 82, 1024-1030. http://dx.doi.org/10.2307/2446232

[20] Spasojevic, M.J., Aichern, R.J., Koch, G.R., Marquardt, E.S., Mirotchnick, N., Troxler, T.G. and Collins, S.L. (2010) Fire and Grazing in a Mesic Tallgrass Prairie: Impacts on Plant Species and Functional Traits. Ecology, 91, 1651-1659.

[21] Jacquin, A. and Goulard, M. (2013) Using Spatial Statistics Tools on Remote-Sensing Data to Identify Fire Regime Linked with Savanna Vegetation Degradation. International Journal of Agricultural and Environmental Information Systems, 4, 69-83.

[22] Bailey, R.G., Avers, P.E., King, T. and McNab, W.H. (1994) Ecoregions and subregions of the United States (Map). In: McNab, W.H. and Bailey, R.G., Eds., Supplementary Table of Map Unit Descriptions, Scale 1:7,500,000. U.S. Department of Agriculture-Forest Service, Washington DC.

[23] U.S. Department of Agriculture (USDA), Natural Resources Conservation Service (NRCS) (2006) Land Resource Regions and Major Land Resource Areas of the United States, the Caribbean, and the Pacific Basin. U.S. Government Printing Office, Washington DC.

[24] Multi-Resolution Land Characteristics Consortium (MRLC) (2013) National Land Cover Database 2006 (NLCD2006). http://www.mrlc.gov/nlcd2006.php

[25] Jacquin, A., Sheeren, D. and Lacombe, J.P. (2010) Vegetation Cover Degradation Assessment in Madagascar Savanna Based on Trend Analysis of MODIS NDVI Time Series. International Journal of Applied Earth Observation and Geoinformation, 12, 3-10.

[26] Verbesselt, J., Hyndman, R., Newnham, G. and Culvenor, D. (2010) Detecting Trend and Seasonal Changes in Satellite 
Image Time Series. Remote Sensing of Environment, 114, 106-115.

[27] Hutchinson, J.M.S., Jacquin, A., Hutchinson, S.L. and Verbesselt, J. (2015) Monitoring Vegetation Change and Dynamics on U.S. Army Training Lands Using Satellite Image Time Series Analysis. Journal of Environmental Management, 150, 355-366.

[28] Bowman, D.M.J.S., Zhang, Y., Walsh, A. and Williams, R.J. (2003) Experimental Comparison of Four Remote Sensing Techniques to Map Tropical Savanna Fire-Scars Using Landsat-TM Imagery. International Journal of Wildland Fire, 12, 341-348.

[29] Laris, P.S. (2005) Spatiotemporal Problems with Detecting and Mapping Mosaic Fire Regimes with Coarse-Resolution Satellite Data in Savanna Environments. Remote Sensing of Environment, 99, 412-424.

[30] McCullagh, P. and Nelder, J.A. (1989) Generalized Linear Models. Chapman and Hall, London.

[31] Banerjee, S., Carlin, B.P. and Gelfand, A.E. (2004) Hierarchical Modeling and Analysis for Spatial Data. Chapman and Hall/CRC Press, Boca Raton.

[32] Akaike, H. (1974) A New Look at the Statistical Model Identification. IEEE Transactions on Automatic Control, 19, 716-723.

[33] Collett, D. (1991) Modelling Binary Data. Chapman and Hall, London.

[34] Borak, J.S., Lambin, E.F. and Strahler, A.H. (2000) The Use of Temporal Metrics for Land-Cover Change Detection at Coarse Spatial Scales. International Journal of Remote Sensing, 21, 1415-1432.

[35] Serneels, S., Said, M. and Lambin, E.F. (2001) Land-Cover Changes around a Major East African Wildlife Reserve: The Mara Ecosystem. International Journal of Remote Sensing, 22, 3397-3420.

[36] Jacquin, A. (2010) Dynamique de la végétation des savanes en lien avec l'usage des feux à Madagascar: Analyse par série temporelle d'images de télédétection. Ph.D. Dissertation, University of Toulouse, Toulouse.

[37] Shaw, R.B. and Diersing, V.E. (1989) Allowable Use Estimates for Tracked Vehicular Training on Pinon Canyon Maneuver Site, Colorado, USA. Environmental Management, 13, 773-782.

[38] Trumbell, V., Dubois, L., Brozka, P.C. and Guyette, R. (1994) Military Camping on Vegetation and Soils of the Ozark Plateau. Journal of Environmental Management, 40, 329-339.

[39] Whitecotton, R.C.A., David, M.B., Darmody, R.G. and Price, D.L. (2000) Impact of Foot Traffic from Military Training on Soil and Vegetation Properties. Environmental Management, 26, 697-706.

[40] Guretzky, J., Anderson, A. and Fehmi, J. (2006) Grazing and Military Vehicle Effects on Grassland Soils and Vegetation. Great Plains Research, 16, 51-61.

[41] Johnson, S., Wang, G., Howard, H. and Anderson, A.B. (2011) Identification of Superfluous Roads in Terms of Sustainable Military Land Carrying Capacity and Environment. Journal of Terramechanics, 48, 97-104.

[42] Ansley, R.J., Pinchak, W.E., Teague, W.R., Kramp, B.A. and Barnett, K. (2010) Integrated Grazing and Prescribed Fire Restoration Strategies in a Mesquite Savannah: II. Mesquite Landscape Cover Responses. Rangeland Ecology and Management, 63, 286-297.

[43] Towne, E.G. and Kemp, K.E. (2008) Long-Term Response Patterns of Tallgrass Prairie to Frequent Summer Burning. Rangeland Ecology \& Management, 61, 509-520. http://dx.doi.org/10.2111/08-043.1

[44] Althoff, P.S., Todd, T.C., Thien, S.J. and Callaham, M.A. (2009) Response of Soil Microbial and Invertebrate Communities to Tracked Vehicle Disturbance in Tallgrass Prairie. Applied Soil Ecology, 43, 122-130. 